\title{
Introducerende note til Bernhard Blanke: Socialdemokrati og samfundskrise
}

\section{Nils Bredsdorff og Leif Hansen}

Den følgende artikel er oprindeligt trykt i Wolfgang Luthardt, (red.): Sozialdemokratische Arbeiterbewegung und Weimarer Republik. Materialien zur gesellschaftlichen Entwicklung 1927-1933, 2. Bd., Frankfurt/M 1978, der omkring en række centrale problemstillinger har genoptrykt tekster fra den omhandlede periode og forsynet disse med kortere indledningsartikler. I denne sammenhæng står Blankes artikel dog ikke som indledning til et tekstudvalg, men netop som materialesamlingens afsluttende, fors øgsvise syntetiserende bidrag.

Socialdemokrati og samfundskrise kalder Blanke sin artikel, men den vigtigste pejling til forståelsen af artiklens hovedsigte fås af undertitlen: Hypoteser til en socialvidenskabelig reformismeteori. Grundlaget - den historiske ramme om man vil - for artiklen er debatten om arbejderbevægelsens (specielt den socialdemokratiske) rolle under Weimarrepublikken, men sigtet er teoridannende.

Blankes projekt er at nå frem til en forståelse af de strukturer i kapitalismen, der gør den reformistiske arbejderbevægelse i stand til ikke blot at overleve alle sine nederlag (og Weimarrepublikkens sammenbrud er et af de store), men til at genopstå styrket og vital.

Artiklen er på den ene side et opgør med de gængse forklaringsmønstre (både borgerlige og marxistiske) omkring (Weimar-) reformismen, som enten ser reformismen som handlingsblokerende for en i sig selv revolutionær eller i det mindste reformivrig arbejderklasses krav, eller som ser reformismen som en bevidst valgt strategi for en arbejderbevægelse, der har ladt de socialistiske forhåbninger bag sig. I sin kritik af den meget omfattende litteratur om weimarperiodens socialdemokrati er artiklen naturligvis bundet til den historiske periode. Men selvom en del af dens pointer måske forudsætter en del viden om den samfundsmæssige udvikling før og under Weimarrepublikken (hvilket bl.a. kan hentes i det to-binds-værk artiklen afslutter), så leverer artiklen samtidig et godt grundlag for at rydde ud i myterne $\mathrm{i}$ diskussionen af baggrunden for overgangen til det fascistiske barbari.

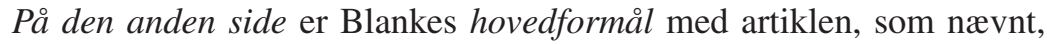
noget bredere, nemlig i egentligste forstand teoridannende. Det drejer sig for det første om et opgør med de samfundsteoretiske forudsatninger for de kritiserede analyser hhv. reformismeteorier. 
For det andet er det et fors $\emptyset \mathrm{g}$ på at skitsere en teori om reformismen, som $i k k e$ tager sit udgangspunkt i de politiske handlinger, der er et udtryk for konflikten mellem lønarbejde og kapital, men derimod i de samfundsmæssige strukturer, som sætter både modsætningen mellem lønarbejde og kapital $o g$ betingelserne for denne modsætnings temporære ophævelse eller bedre dens forskellige bevægelsesformer.

Og hermed har vi allerede antydet det tema, der behandles i artiklens indledning og 1. tese: Artiklens ofte stikordsagtige kritik af de teoretiske forudsætninger for de herskende reformismeforklaringer (og det er igen vigtigt at præcisere, at det gælder såvel de borgerlige som de marxistiske) kan sammenfattes under begrebet handlingsteori. Blanke hævder, efter vores mening med rette, at de eksisterende analyser fra Wehler over Groh til Abendroth og Fülbert/Harrer (det samme gælder i øvrigt for størstedelen af den danske reformismediskussion, jvf. kritikken af de »socialhistoriske « bidrag i Bredsdorff m.fl. i Kurasje 21) basalt har samme samfundsteoretiske udgangspunkt: Samfundet forstås som en »handlingssammenhæng «, dvs. samfundets strukturer og institutioner og ændringer heri forstås alene udfra og som et resultat af (formålsbestemt) individuel eller kollektiv handlen.

Der kan være grund til at knytte nogle få bemærkninger til dette forhold, da det er temmelig centralt for artiklen, men samtidig i sin knappe form kan være vanskeligt at overskue, eftersom Blanke med den indledende kontrastering mellem handlingsteori og systembetragtning (uden i øvrigt selv at gøre opmærksom derpå) skriver reformismedebatten ind i et af de væsentligste samfundsvidenskabelige stridsemner: Hvilke af disse teoretiskmetodiske udgangspunkter skal man tage ved analysen af samfundet?

Siden begyndelsen af dette århundrede har der inden for samfundsvidenskaberne eksisteret en stærk og efter trediverne dominerende og til tider næsten enerådende tradition, der på grundlag af en »metodologisk individualisme « har taget udgangspunkt i individernes/aktørernes handlinger i forsøgene på at forklare samfundsmæssige strukturer og funktioner og $\mathrm{i}$ sidste instans også samfundet som system. Stikordsagtigt drejer det sig om den subjektive værditeori inden for $\emptyset$ konomien, om behavioralismen og strukturfunktionalismen inden for politologien. Disse teoriers praktiskpolitiske bias er ofte blevet kritiseret gennem årene (f.eks. deres im- og eksplicitte regulerings- og manipulationsintention), hvorimod deres teoretisk-metodiske grundlag stadig står forholdsvis uantastet tilbage ofte kun postulatorisk modstillet til en marxistisk system/totalitetsbetragtning. 
Det er imidlertid ikke de fundamentale problemer i den handlingsteoretiske samfundsteori Blanke indledningsvis (utilladeligt kort) polemiserer imod, men snarere mod resultaterne af en - oftest implicit - anvendelse af et sådant udgangspunkt i historieforskningen, in casu om reformismen. Det afgørende problem er, at udgangspunktet ikke gør det muligt at undersøge spørgsmålet om de samfundsmæssige/systemsatte betingelser for og virkninger af den politiske handlen. Dette giver sig bl.a. udslag i den relative vilkårlighed, med hvilken forskellige historikere fremhæver eller udelader bestemte samfundsmæssige forhold i deres reformismeforklaring.

Heroverfor fors $\emptyset$ ger Blanke at arbejde videre med begreber, som er udviklet tidligere i den statsteoretiske debat. Det drejer sig om det i artiklen kun implicit forudsatte begreb om transformationen af herredømme-konflikten til en fordelingskonflikt, som strukturelt er sat af den form, hvori forholdet mellem lønarbejde og kapital fremtræder. Og om det hér ligeledes blot forudsatte begreb om retten og pengene som forhåndsstrukturerende for de agerendes handlingshorisont (jvf. kort Kurasje nr. 21, s. 37 ff). I fors $\varnothing-$ get på at konkretisere og videreudvikle disse bestemmelser til en historisk analyse fastholder Blanke sit »systemudgangspunkt « og gør det endog på en ret provokerende måde, idet han (jvf. note 6): »forsøger at overføre impulser fra den funktionel-strukturelle systemteori (Niklas Luhmanns systemteori, NB \& LH) på det marxistiske paradigma «. Det sker i en præcisering af begreberne systemgranser og aktivitetsgranser for de statlige tiltag, men først og fremmest i forsøget på at bestemme det i artiklen helt centrale begreb: Reformers funktionelle ambivalens.

Overfor Luhmanns position, at den samme funktion kan opfyldes af forskellige strukturer og processer, der er komplementære (funktionel ækvivalens) vil Blanke med begrebet funktionel ambivalens angive, at den samme funktion er bestemt af forskellige relationer, der netop ikke er komplementære, men antagonistiske/modsigelsesfulde og historisk bestemte, hvilket gør processen og strukturen i funktionsopfyldelsen ambivalent (jvf. også B. Blanke. Entscheidungsanarchie und Staatsfunktionen, in: $R$. Ebbighausen (red), Bürgerlicher Staat und politische Legitimation, F/M 1976, s. 188 f.).

I analysen af reformerne, der opfattes som problemløsninger og konfliktreguleringer, viser Blanke nu, hvordan reformerne i deres gennemsættelsesproces er bundet til disse modsigelsesfyldte relationer uden umiddelbart selv at udtrykke modsigelserne, og hvordan reformerne gennem vedvarende institutionalisering udvikler sig til et system til reproduktion af lфnarbejdet. Der er ikke tale om konstruktionen af et system, inden for hvis 
rammer individerne handler, og som derfor altid i sidste instans kan påkaldes som forklaringsinstans overfor uforklarlige eller uønskede handlinger eller konsekvenser heraf. Derimod er der tale om en begrebsliggørelse af forhold, som under kapitalismen tvangsmæssigt strukturerer handlinger og deres institutionalisering, individernes forståelse af disse handlinger og deres forsøg på at uddrage handlingsrettede strategier af denne forståelse.

Vi ser selv Blankes - ofte meget skitseprægede og komprimerede og ind i mellem uoverskuelige - analyse som et af de seneste års vigtigste bidrag inden for den marxistiske teoretiske debat om reformismens reproduktionsbetingelser og som et godt grundlag for en videreudvikling heraf og dermed også mere alment af forholdet mellem økonomi og politik under kapitalismen.

Samtidig aktualiserer Blankes artikel nødvendigheden af et videre arbejde med helt fundamentale samfundsvidenskabelige problemstillinger, som det ovennævnte forhold mellem »handlingsteori« og »strukturteori«, idet artiklen demonstrerer, at en sådan afklaring er nødvendig også for den marxistiske teoriudvikling. 